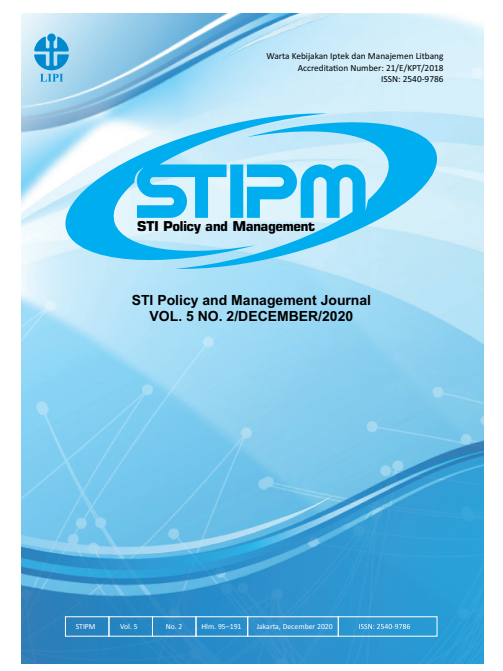

Journal of STI Policy and Management

Publication details, including instructions for authors and subscription information: http://www.stipmjournal.org/

\title{
Eco-Innovation Research in Indonesia: A Systematic Review and Future Directions \\ Budi Harsanto
}

Department of Management and Business, Universitas Padjadjaran, Indonesia

Version of record first published: 15 December 2020

To cite this article: Harsanto, B. (2020). Eco-Innovation Research in Indonesia: A Systematic Review and Future Directions. Journal of STI Policy and Management, 5(2), 179-191.

To link to this article: http://dx.doi.org/10.14203/STIPM.2020.281

ISSN 2540-9786 (Print); ISSN 2502-5996 (online)

Accreditation Number: 21/E/KPT/2018

Full terms and conditions of use: https://creativecommons.org/licenses/by-nc-sa/4.0/

You are free to:

- Share : copy and redistribute the material in any medium or format

- Adapt : remix, transform, and build upon the material

- The licensor cannot revoke these freedoms as long as you follow the license terms.

Under the following terms:

Attribution - You must give appropriate credit, provide a link to the license, and indicate if

(1) changes were made. You may do so in any reasonable manner, but not in any way that suggests the licensor endorses you or your use.

NonCommercial - You may not use the material for commercial purposes.

ShareAlike - If you remix, transform, or build upon the material, you must distribute your contributions under the same license as the original.

No additional restrictions - You may not apply legal terms or technological measures that legally restrict others from doing anything the license permits.

Notices:

- You do not have to comply with the license for elements of the material in the public domain or where your use is permitted by an applicable exception or limitation.

- No warranties are given. The license may not give you all of the permissions necessary for your intended use. For example, other rights such as publicity, privacy, or moral rights may limit how you use the material.

- If you copy the dataset merely to extract the uncopyrightable data elements would not need permission to do so. However, if you republish the full dataset or using the copyrightable data layers require permission from the Research Center for STIPM, Indonesian Institute of Sciences. 


\title{
JOURNAL OF SCIENCE, TECHNOLOGY AND INNOVATION POLICY AND MANAGEMENT (STIPM JOURNAL), Volume 05, Issue 02, December 2020
}

\author{
FOREWORD by EDITOR-in-CHIEF
}

We are pleased to present to the readers with the fifth issue of the Journal of Science, Technology and Innovation Policy and Management. In this issue, we continue to publish the results of interdisciplinary scientific researches in various aspects of STI Policy and Management. This issue, prior issues, and other resources are available at www.stipmjournal.org.

We thank the reviewers and editorial boards for taking their precious time to ensure the quality of the articles through the double-blind peer review process. The seven articles in this volume cover a wide range of topics in STI policy and R\&D governance and management. In this issue, we introduce a special topic on Original Concept Formation. This is a new focus and scope of STI Policy and Management Journal. A concept formation in technology policy (TP) and management of technology (MOT), including proven soft technology concept based on rigorous data, cumulatively published references, and long experiences in the academic sphere. The original concept formation should deal with soft technology problems, policy context for problem-solving, concept formation, and its effective implementation.

M. Nawaz Sharif presents an original concept formation entitled Technology for Development: Ten True Stories Revealing the Complexity of Replicating South Korean Success. The essay comprises ten true stories presented to highlight personally observed problems encountered by Asian developing country leadership who tried to replicate South Korean success in fostering technology innovation induced sustainable economic growth strategy without paying robust attention to the crucial role of creating an "innovation climate/culture" as a necessary foundation for myriad development efforts.

The subsequent articles revealed research findings on the various issue of STI policy and R\&D governance and management. First article is presented by Erwiza Erman entitled Changing Stages of System Innovation at the Ombilin's Coal Mines of Sawahlunto: From Ghost Town to World Heritage. This paper examines system innovation, a transition from one socio-technical system to another by transforming the historical and cultural area into a world heritage city. The objective of this study is to reconstruct the changing stages of system innovation in achieving the World Heritage status at the Ombilin coal mines site of Sawahlunto.

The second article is composed by Rachmini Saparita and Savitri Dyah, entitled Mechanism of Implementing Technology in the Community of Eastern Indonesia (Case Study in Belu Regency, Nusa Tenggara Timur Province). This paper focuses on the mechanism of technology implementation to increase society's welfare. The study also evaluated technology implementation activities in the period 2003 to 2019, using meta-synthesis. The analysis found that there are five types of technology transfer mechanisms carried out by researchers at LIPI. 
The third article is composed by Budi Triyono, Ria Hardiyati, and Aditya Wisnu Pradana, entitled Lack of Contribution of the Indonesian R\&D Program to Economic Sector: Learning from the RPJMN Implementation. Through a review of the National Medium-Term Development Plan (RPJMN) documents on the S\&T Sector period of 2015-2019, this article attempts to analyze various obstacles related to the minimal contribution of Indonesian R\&D Programs in supporting Indonesia's economic sector and national competitiveness.

Wati Hermawati presents an article entitled Key Success Factors in Managing and Implementing Public Funded R\&D Projects in Indonesia. In this paper, she mentioned that the role of public-funded $\mathrm{R} \& \mathrm{D}$ institutions in supporting innovation and economic performance of MSMEs (micro, small and medium enterprises) is still very small. Therefore, the success factors in managing and implementing $R \& D$ projects at $R \& D$ institutions should be identified, particularly in providing solution for MSMEs' problems. Through the two case studies, this article provides key success factors and lessons learned to improve R\&D project activities at PRCs.

The fifth article is presented by Trina Fizzanty, Kusnandar, Sigit Setiawan, Radot Manalu, and Dini Oktaviyanti, entitled The International Research Collaboration, Learning and Promoting Innovation Capability in Indonesia Medical Sectors. This article presents the case of eight international collaborative research projects in medical research in Indonesia. The research found that International research collaboration has opened the opportunity for Indonesian researchers to learn and upgrade their capability and contribute to the scientific arena. However, none of international research projects reached the commercialization stage yet, but some of which were at the beginning of clinical trial stage.

Finally, Budi Harsanto presents an article entitled Eco-innovation Research in Indonesia: A Systematic Review and Future Directions. The article analyzes the recent development of eco-innovation research in Indonesia and provides some potential avenues for future research. The analysis was carried out using Systematic Literature Review (SLR) techniques to synthesize knowledge development of a scientific field in a structured, transparent, and reliable manner.

The editor of STIPM Journal are dedicated to working with scholars in existing and emerging STI issues and produce high-quality papers to expand knowledge in the field of STI Policy and R\&D Governance and Management. We believe that all the papers published in this issue will greatly influence on the STI Policy and Management for Sustainable Development.

The STIPM Journal is indexed by Google Scholar, ISJD, IPI, DOAJ, BASE, SINTA, and OCLC World Cat. This makes the journal dissemination wider.

The editor-in-chief acknowledge and are very grateful to the authors, the editorial board, the section editors, the designer, the staff of the LIPI Press Publishing Office, and everyone who has contributed to the publication of the STIPM journal. We are also very grateful to our future readers. By inviting the readers to publish your research results articles in this journal, we believe in the meaningfulness and future collaboration as well as to provide a higher scientific platform for the authors and the readers, with a comprehensive overview of the most recent STI Policy and Management research and development at the national, regional, and international level.

Happy New Year 2021 to all of you!

Jakarta, 15 December 2020

Editor-In-Chief 



\section{JOURNAL OF STI POLICY AND MANAGEMENT}

Volume 5, Number 2, December 2020

\section{LIST OF CONTENTS}

Technology for Development: Ten True Stories Revealing the Complexity of Replicating South Korean Success

M. Nawaz Sharif.

Changing Stages of System Innovation at the Ombilin's Coal Mines of Sawahlunto: From Ghost Town to World Heritage

Erwiza Erman

Mechanism of Implementing Technology in the Community of Eastern Indonesia (Case Study in Belu Regency- Nusa Tenggara Timur Province)

Rachmini Saparita and Savitri Dyah

The Gap between Program Planning and Implementation: The Case of R\&D Program in Indonesian RPJMN

Budi Triyono, Ria Hardiyati, and Aditya Wisnu Pradana

Key Success Factors in Managing and Implementing Public Funded R\&D Projects in Indonesia

Wati Hermawati

The International Research Collaboration, Learning and Promoting Innovation Capability in Indonesia Medical Sectors

Trina Fizzanty, Kusnandar, Sigit Setiawan, Radot Manalu, and Dini Oktaviyanti

Eco-Innovation Research in Indonesia: A Systematic Review and Future Directions 



\title{
it STI POLICY AND MANAGEMENT \\ LIPI Journal homepage: http://www.stipmjournal.org
}

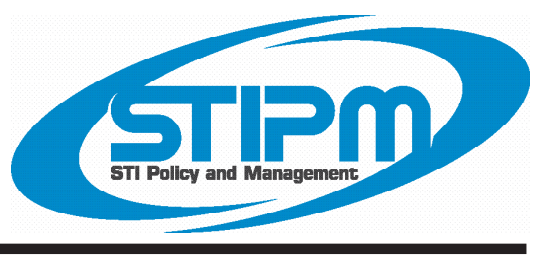

\section{Eco-Innovation Research in Indonesia: A Systematic Review and Future Directions}

\author{
Budi Harsanto*
}

a Department of Management and Business, Universitas Padjadjaran, Indonesia

\begin{tabular}{|c|c|}
\hline ARTICLE INFO & ABSTRACT \\
\hline Article History: & \multirow{14}{*}{$\begin{array}{l}\text { Innovation by considering the impact to the ecological environment, } \\
\text { known as eco-innovation, continues to receive increasing attention } \\
\text { in at least the past two decades. This paper provides an analysis } \\
\text { of the recent development of eco-innovation research in Indonesia } \\
\text { and provide some potential avenues for future research. The } \\
\text { analysis is carried out using systematic literature review (SLR) } \\
\text { techniques to synthesize knowledge development of a scientific } \\
\text { field in a structured, transparent, and reliable manner. The search was } \\
\text { conducted on three academic databases, including Scopus, Google } \\
\text { Scholar, and the local academic database of Garuda (Garba Rujukan } \\
\text { Digital). Data were analyzed using content analysis. The analysis } \\
\text { shows that the scholarly publication of eco-innovation research in } \\
\text { Indonesia is still rare. The topics discussed can be categorized into } \\
\text { several categories, such as the driver of eco-innovation, R\&D for } \\
\text { eco-innovation, and eco-innovation performance, which addresses } \\
\text { various types of eco-innovation and different levels of analysis. } \\
\text { Potential research avenues are then identified at the end of the paper. } \\
\text { This is the first systematic review on eco-Innovation in Indonesia, } \\
\text { and the first combining systematic search strategy using both local } \\
\text { and international academic databases. }\end{array}$} \\
\hline Received : 28 June 2020 & \\
\hline Revised : 13 October 2020 & \\
\hline Accepted : 14 October 2020 & \\
\hline Available online : 15 December 2020 & \\
\hline $\begin{array}{l}\text { Authorship Contribution: } \\
\text { Author is the main contributor. }\end{array}$ & \\
\hline Keywords: & \\
\hline Eco-innovation, & \\
\hline Innovation, & \\
\hline Systematic review, & \\
\hline Indonesia & \\
\hline & \\
\hline & \\
\hline & \\
\hline
\end{tabular}

\section{INTRODUCTION}

Eco-innovation is various forms of innovation in production and consumption activities that can reduce negative impacts on the environment or improve the ecological environment while minimizing the exploitation of natural resources (Jo et al., 2015; Kemp \& Pearson,

* Corresponding Author.

E-mail: budi.harsanto@unpad.ac.id
2007). Eco-innovation is considered as the key in transitioning to a more competitive as well as a sustainable economy (Kiefer et al., 2017). Concern for eco-innovation has continued to increase in the last few decades in the domain of academic, practice, as well as in the policy domain due to the increased pressure for companies as economic agents to be more aware of the consequences of their activities (Díaz-García, González-Moreno, \& Sáez-Martínez, 2015). 
Studies on eco-innovation had immensely grown over the years (Hazarika \& Zhang, 2019). Publications on this topic developed dramatically from about ten publications per year in the 1990s to around more than 500 publications per year in 2007, with most researchers located in Europe (Schiederig et al., 2012). This research has drawn attention from a variety of different perspectives such as business and economics, environmental science, engineering, and other disciplines (Schiederig, Tietze, \& Herstat 2012; Xavier et al., 2017).

Although growing so rapidly, it is still unclear how the development of eco-innovation research in Indonesia is progressing. For Indonesia, the challenge of environmental degradation is real (Gumbira \& Harsanto 2019; Ministry of Environment and Forestry Indonesia 2017). It is evidenced among others by the data from the Ministry of Environment and Forestry Indonesia (2017), which revealed that more than 125 million tons of hazardous and toxic waste were generated from the mining, energy, manufacturing, agroindustry, infrastructure, and service sectors.

From an environmental perspective, a recent report from OECD (2019) highlighted that the economic growth experienced by Indonesia is accompanied by increasing pressure on the environment. More than $90 \%$ of Indonesia's population is exposed to air pollution, which is dangerously above the WHO reference value threshold, mainly caused by transportation, power plants, coal, burning waste, as well as forest and peatland fires (OECD, 2019). Furthermore, Indonesia has only one disposal site for toxic and hazardous materials, and for water pollution, it is estimated that less than $15 \%$ of the wastewater is treated (OECD, 2019).

As for innovation, Indonesia also faces considerable challenges. In the 2020 Global Innovation Index, Indonesia is ranked 85th, unchanged from the previous year (Cornell University, INSEAD and WIPO, 2020). Among middle-income economies in Southeast Asia, this ranking is relatively low when compared to neighbors such as Malaysia (33), Vietnam (42), Thailand (44), or the Philippines (50). Of the many indicators used in the Global Innovation
Index, the ones that have enough weaknesses for Indonesia is 'human capital and research' (Cornell University et al., 2020).

This paper has two aims, first to provide an analysis of the recent development of eco-innovation research in Indonesia by a systematic review of relevant publications in several academic databases and to provide some potential avenues to be explored in future research in the context of Indonesia. To the best of the author's knowledge, there is no systematic review on eco-innovation in Indonesia has been undertaken. Therefore, this paper makes an original contribution and offers important insights into the eco-innovation field in this specific context.

The remainder of this paper proceeds as follows. Section II discusses theoretical concepts on eco-innovation as a basis for analysis. Section III discusses detail on methodology. Section IV discusses findings and discussions, as well as several potential research avenues. Finally, the conclusion is provided in Section V.

\section{THEORETICAL CONCEPT}

The eco-innovation concept can be traced back to the 1960s when Ernst Schumacher introduced the term intermediate technology, or appropriate technology, which emphasized the achievement of goals by minimizing environmental degradation and resource consumption (Hazarika \& Zhang, 2019). Eco-innovation is also known as ecological innovation, green innovation, or environmental innovation (Schiederig et al., 2012). Within a broader scope, this terminology is also known as sustainability innovation or sustainability-oriented innovation (Harsanto, Michaelides, \& Drummond 2018; Varadarajan 2017). The difference is that eco-innovation terminology emphasizes the environmental aspects of innovation, while sustainability innovation emphasizes both environmental and social aspects (Harsanto \& Permana, 2019).

Eco-innovation is defined differently in the literature. One widely adopted definition was offered by Kemp \& Pearson (2007):

"Eco-innovation is the production, assimilation 
service or management or business method that is novel to the organization (developing or adopting it) and which results, throughout its life cycle, in a reduction of environmental risk, pollution and other negative impacts of resources use (including energy use) compared to relevant alternatives" (Kemp \& Pearson, 2007, pp.7)

Studies on eco-innovation have occurred since the 1990s and have experienced significant development since the 2000s (Schiederig et al., 2012). This development is in line with increasing environmental degradation as a result of industrialization (Harsanto et al. 2020). The end-of-pipe approach, where pollution is handled only at the end of the production process, is considered no longer effective and efficient because environmental impacts can occur on all production cycles (Xavier et al., 2017). Hence it is not surprising that eco-innovation is not only limited to product and process innovation but also to organizational innovation.

The implementation of product eco-innovation for example in the form of eco-design (Bos-brouwers, 2010), ecolabel (Hitchens et al., 2005), or eco-packaging (Fernández-Viñé, Gómez-Navarro, \& Capuz-Rizo, 2010). Process eco-innovation, for example, is implemented in the form of cleaner production (HowgraveGraham \& van Berkel, 2007) or eco-efficiency (Aragón-Correa et al., 2008). Organizational eco-innovation could be implemented in the form of integrating environmental aspects in the organization management systems (Machiba, 2010).

There are several specific themes researched, such as drivers for eco-innovation, processes of eco-innovation development, outcomes of ecoinnovation, different types of eco-innovation, and policy evaluations to help the diffusion of eco-innovation (Díaz-García et al., 2015).

Drivers of eco-innovation may come from internal and external companies. Internally, it is related to the supply side, such as technological capabilities (technology push) and internal motivations, for example, to enhance reputation (Harsanto \& Permana 2020; Horbach 2008). Externally, the driver is related to the demand side (demand-pull), such as social awareness of the market, as well as institutional and political influences such as regulations and incentives (Horbach, 2008).

The process of eco-innovation includes various activities to develop eco-innovation, for example, through $\mathrm{R} \& \mathrm{D}$ management or developing models for piloting eco-innovation in organizations (Lee \& Min, 2015). Outcomes of eco-innovation are measurable results or performance resulting from eco-innovation initiatives. This performance can take the form of financial performance, such as profitability or non-financial such as company competitiveness or company reputation or market value (Zhang \& Walton, 2017).

Eco-innovation is studied at various levels of analysis from the micro-level by emphasizing the internal aspects of the company (Kesidou \& Demirel, 2012), dynamics and pressure groups (De Marchi, 2012) and macro-level regarding policy instruments, and innovation systems (Triguero, Moreno-Mondéjar, \& Davia, 2013).

\section{METHODOLOGY}

The methodology used in this paper is a systematic literature review (SLR). SLR is a methodology to synthesize the development of a field by searching and analyzing literature in a structured and transparent manner so that it can be concluded clearly what is known and what is not yet known (Denyer \& Tranfield, 2009).

\section{Eligibility Criteria}

Several eligibility criteria were determined to achieve the research objectives.

a) The document should contain research on eco-innovation, which is reflected in the articles' title, abstract and keywords.

b) It should be published in peer-reviewed journal articles to obtain quality literature scrutinized by peer reviewers. Literature in the form of proceedings or books or research reports or another type of documents is excluded. This criterion has commonly been used to get quality reviews (Klewitz \& Hansen, 2014). 
c) It should be empirical research. Conceptual and theoretical papers are excluded.

d) It should be in English or Bahasa Indonesia.

\section{Search Strategy}

The search was located on three academic databases, Scopus, Google Scholar, and Garuda (Garba Rujukan Digital). The combination of international and local databases is useful for capturing research that is not indexed in international databases. Each database has its own search syntax characteristics. In general, the search syntax used was as follows ((eco $A N D$ innovation) OR (ecological AND innovation) $O R$ (green AND innovation)) AND Indonesia))). Eco (or ecological) and 'green innovation' are the two main terms that can be used to identify research on eco-innovation (Xavier et al., 2017). Eco (or ecological) is the main term that as the focus of the search in this paper and green innovation is the companion term. In Indonesian context, the 'green innovation' term is more popularly used instead of 'environmental innovation'; hence the search is focused on eco and 'green innovation' (Kemenperin, 2016). The search process was performed several times in June 2020.

A rough search from three academic databases produced 90 search results. After duplica-

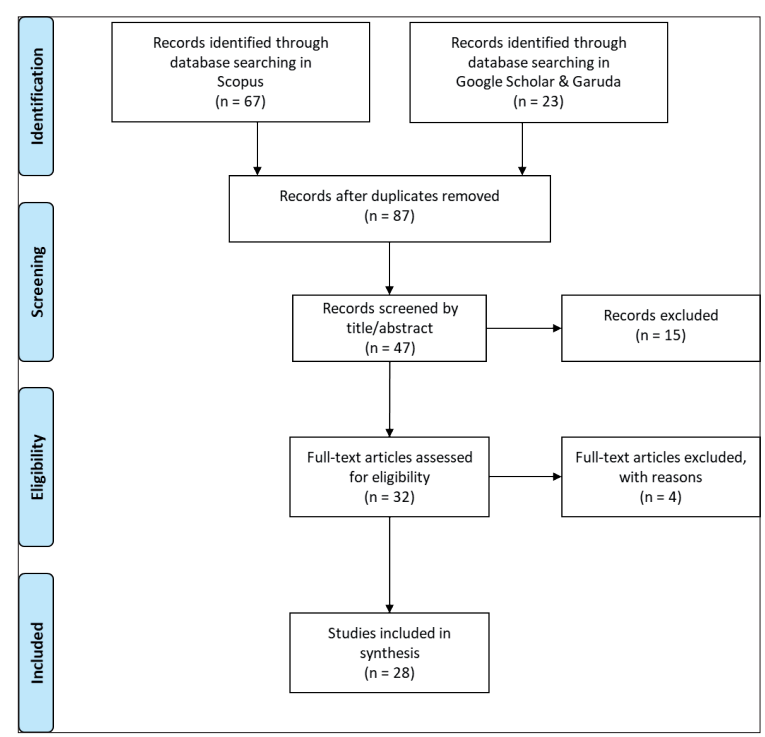

Source: Moher et al. (2009)

Figure 1. Search and Screening Process Adapted from the PRISMA Flow Diagram tion was removed, it obtained 87 results. The title and abstract are then read manually to determine their compatibility with eligibility criteria. From this process, 47 articles were obtained. Then full paper assessment is conducted and results in 32 articles. During the coding process, the full paper was re-read and re-assessed, resulting in 28 articles as the final list for review. The filtering process is shown in Fig. 1, which is adopted from the Preferred Reporting Items for Systematic Reviews and Meta-Analyses (PRISMA) flow diagram (Moher et al., 2009).

\section{Data Analysis}

Data were analyzed using content analysis. Content analysis is a qualitative research approach for extracting data and making inferences systematically and objectively based on specific coding techniques (Hsieh \& Shannon 2005; Krippendorff 1980; Stemler 2001). The articles' content in the form of a sentence or paragraph is extracted from each article. A coding scheme based on a theoretical concept of eco-innovation was developed inductively (Table 1).

The extracted data was then coded and analyzed based on the coding scheme (Geyh et

Table 1.

Coding Scheme

\begin{tabular}{ll}
\hline \multicolumn{1}{c}{ Code } & \multicolumn{1}{c}{ Code Definition } \\
\hline Driver & $\begin{array}{l}\text { The statement describes the antecedents } \\
\text { for eco-innovation. }\end{array}$ \\
\hline Process & $\begin{array}{l}\text { The statement describes the process of } \\
\text { developing eco-innovation, mainly R\&D. }\end{array}$ \\
\hline Outcome & $\begin{array}{l}\text { The statement describes the performance } \\
\text { impact of eco-innovation. It is differenti- } \\
\text { ated into two subgroups: }\end{array}$ \\
& $\begin{array}{l}\text { Financial performance } \\
\text { Non-financial performance }\end{array}$ \\
\hline Type & $\begin{array}{l}\text { The statement describes the type of eco- } \\
\text { innovation discussed. It is differentiated } \\
\text { into three subgroups: } \\
\text { Product eco-innovation } \\
\text { Process eco-innovation } \\
\text { Organizational eco-innovation }\end{array}$ \\
\hline $\begin{array}{l}\text { The statement describes the level or focus } \\
\text { of the analysis of the study. It is differenti- } \\
\text { ated into three subgroups: } \\
\text { Company or organization } \\
\text { Business environment, incl. market } \\
\text { Policy and innovation system }\end{array}$
\end{tabular}


al., 2011). Qualitative NVivo 12 Pro software is used to assist the coding and analysis process.

\section{RESULTS AND DISCUSSION}

\section{Characteristics}

The analysis of the characteristics of the paper reviewed is shown in Table 2. It is found that studies on eco-innovation in Indonesia were first published in 2013. The trend of publication continues to increase from year to year, although it can be said to be generally low, on average only at 3.5 articles per year ( 28 articles/ 8 years) compared to more than 500 articles per year published on this topic globally. Most of it has been published in English (85.7\%), so it can be read by international readers. Methodologically, the quantitative approach dominates these studies $(82.1 \%)$.

Table 2.

Characteristics of Papers Analyzed

\begin{tabular}{lll}
\hline \multirow{2}{*}{ Characteristics } & \multicolumn{2}{c}{ Frequency } \\
\cline { 2 - 3 } & \multicolumn{2}{c}{$\mathbf{N}$} \\
\hline Publication year & 1 & 3.57 \\
\hline 2013 & 3 & 10.71 \\
\hline 2014 & 3 & 10.71 \\
\hline 2015 & 2 & 7.14 \\
\hline 2016 & 2 & 7.14 \\
\hline 2017 & 9 & 32.14 \\
\hline 2018 & 5 & 17.86 \\
\hline 2019 & 3 & 10.71 \\
\hline 2020 & & \\
\hline Language & 4 & 14.29 \\
\hline Bahasa Indonesia & 24 & 85.71 \\
\hline English & & \\
\hline Methodology & 23 & 82.14 \\
\hline Quantitative & 5 & 17.86 \\
\hline Qualitative & 0 & 0.00 \\
\hline Mixed & & \\
\hline Journal rank & 1 & 3.57 \\
\hline Scopus Q1 & 11 & 39.29 \\
\hline Scopus Q2 & 5 & 14.29 \\
\hline Scopus Q3 & 2 & 7.14 \\
\hline Scopus Q4 & 0 & 0.00 \\
\hline Sinta S1 & 4 & 14.29 \\
\hline Sinta S2 & 3 & 3.57 \\
\hline Sinta S3-S4 & 10.71 \\
\hline Sinta S5-S6 & & \\
\hline NA & & \\
\hline Sourc: & & \\
\hline 2014 \\
\hline 2019
\end{tabular}

Source: data processed by the author (2020)
Regarding journal rank, for the international journal, there is only one study that was published in the Q1 journal. For national journals, the number of publications in $\mathrm{S} 1$ and $\mathrm{S} 2$ is quite balanced with those in lower-ranked journals ( $\mathrm{S} 3$ to $\mathrm{S} 6$ ). These results indicate that eco-innovation studies in Indonesia are published in various journals of different ranks.

Some selected papers prominent in terms of journal quality or citation level can be seen in Table 3. There are only two papers published in international journals with impact factor (Clarivate Analytics, 2018) published in Journal of Cleaner Production both from Universitas Indonesia (Latupeirissa \& Adhariani, 2020) and published in Sustainability (Switzerland) with affiliation STIA and Manajemen Kepelabuhan Barunawati/Research Synergy Foundation and Czestochowa University of Technology Poland/ North-West University South Africa (Rajiani \& Kot, 2018).

Papers with high citations published in international journals are published in the In-

Table 3.

Papers in the Journal with IF and Highly-cited

\begin{tabular}{|c|c|c|c|}
\hline Aspects & $\begin{array}{c}\text { Author and } \\
\text { year }\end{array}$ & Journal & Notes \\
\hline \multirow{2}{*}{$\begin{array}{l}\text { Paper in } \\
\text { international } \\
\text { journal with } \\
\text { Impact Factor } \\
\text { (IF) }\end{array}$} & $\begin{array}{l}\text { Latupeirissa } \\
\& \text { Adhariani } \\
\text { (2020) }\end{array}$ & $\begin{array}{l}\text { Journal of } \\
\text { Cleaner } \\
\text { Production }\end{array}$ & $\begin{array}{l}\text { IF } 6.395 \\
\text { (SJR Q1) }\end{array}$ \\
\hline & $\begin{array}{l}\text { Rajiani \& Kot } \\
\text { (2018) }\end{array}$ & $\begin{array}{l}\text { Sustainability } \\
\text { (Switzerland) }\end{array}$ & $\begin{array}{l}\text { IF } 2.592 \\
\text { (SJR Q2) }\end{array}$ \\
\hline \multirow[t]{2}{*}{$\begin{array}{l}\text { Highly-cited } \\
\text { paper in the } \\
\text { international } \\
\text { journal }\end{array}$} & $\begin{array}{l}\text { Fernando, } \\
\text { Shaharudin, \& } \\
\text { Wahid (2016) }\end{array}$ & $\begin{array}{l}\text { International } \\
\text { Journal of } \\
\text { Services and } \\
\text { Operations } \\
\text { Management }\end{array}$ & $\begin{array}{l}\text { Cited } 17 x \\
\text { in GS (SJR } \\
\text { Q2) }\end{array}$ \\
\hline & $\begin{array}{l}\text { Handayani, } \\
\text { Wahyudi, \& } \\
\text { Suharnomo } \\
\text { (2017) }\end{array}$ & $\begin{array}{l}\text { Business: } \\
\text { Theory and } \\
\text { Practice }\end{array}$ & $\begin{array}{l}\text { Cited 20x } \\
\text { in GS (SJR } \\
\text { Q3) }\end{array}$ \\
\hline \multirow[t]{2}{*}{$\begin{array}{l}\text { Highly- } \\
\text { cited paper } \\
\text { in national } \\
\text { journal }\end{array}$} & $\begin{array}{l}\text { Heryanto, } \\
\text { Sukayat, \& } \\
\text { Supyandi } \\
(2014) \\
\end{array}$ & $\begin{array}{l}\text { STI Policy and } \\
\text { Management } \\
\text { Journal }\end{array}$ & $\begin{array}{l}\text { Cited } \\
5 x \text { in GS } \\
\text { (Sinta S2) }\end{array}$ \\
\hline & $\begin{array}{l}\text { Setyawati, } \\
\text { Maarif, \& } \\
\text { Arkeman } \\
(2014)\end{array}$ & $\begin{array}{l}\text { Jurnal Teknik } \\
\text { Industri }\end{array}$ & $\begin{array}{l}\text { Cited } \\
5 x \text { in GS } \\
\text { (Sinta S3) }\end{array}$ \\
\hline
\end{tabular}

Notes: IF based on Clarivate analytics; SJR $=$ Scimago Journal Rank; GS = Google Scholar 
ternational Journal of Services and Operations Management (IJSOM) (Fernando, Shaharudin and Wahid (2016) and in Business: Theory and Practice (Handayani, Wahyudi, \& Suharnomo, 2017). Highly cited papers in the national journal are from Heryanto, Sukaya and Supyandi (2014) published in STI Policy and Management and from Setyawati, Maarif and Arkeman (2014) published in Jurnal Teknik Industri. This finding shows that Indonesian researchers with interest in this topic have the potential to produce publications in highly recognized journals as well as the potential for citation by other researchers in the field.

\section{Content Analysis}

A summary of the content analysis is shown in Table 4 . As with the coding scheme previously prepared, the contents of the paper are analyzed into five qualitative codes, including drivers of eco-innovation, $\mathrm{R} \& \mathrm{D}$ for eco-innovation, ecoinnovation performance, type of eco-innovation, and studies' level of analysis.

\section{a. Driver of eco-innovation}

The driver of eco-innovation is discussed by 10 of the 28 articles reviewed. The drivers of eco-innovation studied are mostly internal driver, including companies' market orientation (Aryanto, Wismantoro, \& Widyatmoko 2019; Fadhilah \& Andriyansah 2017), corporate social responsibility or CSR (Handayani, Wahyudi, \& Suharnomo, 2017), green entrepreneurship orientation (Herman \& Anggraeni, 2015), behavior (Heryanto, Sukayat, \& Supyandi, 2014), green IT/information technology empowerment (Muafi, 2015), technology (Fernando, Shaharudin, \& Wahid, 2016), corporate environmental ethics (Pemayun \& Suprapti, 2016), organizational learning capability (Herman \& Anggraeni, 2015), financial capacity (Sari \& Kusumastuti, 2018) and management accounting system (Zandi et al., 2019). From these results, it is evident that the internal drivers of the company are diverse with different emphasis, such the market, financial, owner or top management orientation, management system, or technology.
Drivers with an emphasis on external relations are linked with social capital that discussed the relationship between elements of the organization and networks outside the company (Muafi, 2015). For example, a green network with suppliers or customers, as found by Fernando, Shaharudin, and Wahid (2016) or political connections with the government as researched by (Latupeirissa \& Adhariani, 2020). Government regulation was also found to be a driver for the development of eco-innovation in the company (Fernando, Shaharudin, \& Wahid 2016; Herman \& Anggraeni 2015). Interestingly, although these external drivers have not been widely researched, two of the four articles that discuss external drivers are published in a journal with impact factor/ highly cited (Fernando, Shaharudin, \& Wahid 2016; Latupeirissa \& Adhariani, 2020).

\section{b. $R \& D$ for eco-innovation}

The process of developing eco-innovation, especially $\mathrm{R} \& \mathrm{D}$, recieved little discussion in the literature (3 of 28 articles). The development process that obtains attention in the literature is knowledge transfer (Zandi, Khalid, \& Islam, 2019), where knowledge in organizations that are mostly tacit (not easily articulated) is disseminated to all parts of the organization or to other relevant parties to improve coordination and achieve better results. Although not directly related to $R \& D$, this process is related to learning within the organization.

The process of developing eco-innovation involving external resources was researched by (Astuti et al., 2019) with a focus on the role of universities in developing all forms of ecoinnovation. Universities as centers of excellence, with their research and academic activities, have been found to be statistically significant in improving the process, organizational and marketing eco-innovation, while it was not statistically significant to improve the product eco-innovation.

\section{c. Eco-innovation performance}

Eco-innovation performance is a topic that is quite widely discussed in the reviewed literature, both financial and non-financial performance (11 and 14 times, respectively). As a note, in some 
studies, the non-financial performance, such as marketing performance, used indicators in the form of financial performance such as sales revenue (Aryanto, Wismantoro, \& Widyatmoko 2019; Fadhilah \& Andriyansah 2017). If this is the case, then the study is considered to examine both financial and financial performance. Some studies focus on financial aspects (Latupeirissa \& Adhariani 2020; Setiawati et al. 2014), some focus on non-financial performance (Fitria \& Yuliana 2018; Pemayun \& Suprapti 2016), and some investigated both financial and non-financial performance (Astuti et al. 2018; Fadhilah \& Andriyansah 2017; Wen \& Harris 2020; Wibowo, Ahmad, \& Fauzi 2019).

Financially, the indicators that represent performance, including profitability (Handayani, Wahyuni, \& Suharmono 2017; Herman \& Anggraeni 2015; Latupeirissa \& Adhariani, 2020), or sales revenue (Aryanto, Wismantoro, \& Widyatmoko 2019; Astuti et al. 2018). Non-financially, there are more indicators researched such as marketing performance (Aryanto (Aryanto, Wismantoro, \& Widyatmoko 2019; Astuti et al. 2018; Fadhilah \& Andriyansah 2017; Lumbanbatu \& Aryanto 2015), production performance (Astuti et al., 2018), market share (Herman \& Anggraeni, 2015), eco-organization in terms of eco-campus for university youth entrepreneurs (Fitria \& Yuliana 2018), reputation and social legitimation (Handayani, Wahyudi, \& Suharmono 2017), or in a wider scope of performance in the form of competitive advantage (Pemayun \& Suprapti, 2016). In general, it is found that eco-innovation influences financial or non-financial performance with detailed effects varying in each of these studies.

\section{d. Type of eco-innovation}

Among the three types of eco-innovation, the most studied are product eco-innovation (14 times), followed by process eco-innovation (10 times), and organizational eco-innovation (3 times). From this analysis, it had clearly seen that there is a fairly large gap in attention between product and process eco-innovation with organizational eco-innovation.
Several studies provide a single focus on product eco-innovation (Alamsyah, Syarifuddin, \& Mohammed 2018; Alvin 2018; Fadhilah \& Andriyansah 2017; Herman \& Anggraeni 2015; Zandi et al. 2019), or a single focus on process eco-innovation (Handayani, Wahyudi, \& Suharmono 2017; Muafi 2015; Setiawati et al. 2014; Wen \& Harris, 2020). Some examine the combination of these two types of eco-innovation together (Lumbanbatu \& Aryanto, 2015) or even all three types of eco-innovation together (Astuti et al., 2018).

\section{e. Level of analysis}

The level of analysis of the studies reviewed is mostly at the organizational or company level (19 times), followed by the business environment (nine times), and policy (one time). The companies studied came from various sizes, both large companies (Latupeirissa \& Adhariani 2020; Lumbanbatu \& Aryanto 2015; Sari \& Kusumastuti 2018; Somjai, Fongtanakit, \& Laosillapacharoen 2020) or small and medium enterprises (SMEs) (Aryanto, Wismantoro, \& Widyatmoko 2019; Astuti et al., 2018; Fadhilah \& Andriyansah 2017; Wibowo, Ahmad, \& Fauzi 2019). SMEs come from different industries such as batik (Aryanto, Wismantoro, \& Widyatmoko 2019; Herman \& Anggraeni 2015) or the creative industry center (Astuti et al., 2019). Besides companies, there is also a discussion in the context of eco-preneurship for an eco-campus (Fitria \& Yuliana, 2018).

For the analysis that focuses on business environments, the most received attention was the market (Alamsyah, Syarifuddin, \& Mohammed 2018; Alvin, 2018; Pemayun \& Suprapti 2016; Rajiani \& Kot 2018). For market, in particular regarding customer behavior, was investigated by (Alamsyah, Syarifuddin, \& Mohammed, 2018), customer perception as researched (Alvin 2018; Pemayun \& Suprapti 2016), or forecasting potential consumers for the aviation industry by (Rajiani \& Kot, 2018). Another analysis that focuses on the business environment such as studied by (Astuti et al., 2019) examined the role of universities in the development of eco-innovation in the industry center of natural stone handicraft, industrial estate as researched by (Hadiwijoyo, 
Table 4.

Content Analysis Recapitulation of Paper Included in the Review (Ordered Alphabetically by First Author Name)

\begin{tabular}{|c|c|c|c|c|c|c|c|c|c|c|}
\hline Author and Year & DRI & RND & PFI & PNF & PDEI & PCEI & OGEI & COM & ENV & PLC \\
\hline $\begin{array}{l}\text { Alamsyah, Syarifuddin, \& } \\
\text { Mohammed (2018) }\end{array}$ & & & & & v & & & & $\checkmark$ & \\
\hline Alvin (2018) & & & & & $v$ & & & & $v$ & \\
\hline $\begin{array}{l}\text { Aryanto, Wismantoro, \& } \\
\text { Widyatmoko (2019) }\end{array}$ & $v$ & & 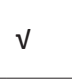 & $v$ & & & & $v$ & & \\
\hline $\begin{array}{l}\text { Astuti, Prawoto, Irawan, \& } \\
\text { Sugiono (2018) }\end{array}$ & & & $\mathrm{V}$ & $v$ & v & v & $v$ & $v$ & & \\
\hline $\begin{array}{l}\text { Astuti, Prawoto, Irawan, \& } \\
\text { Sugiono (2019) }\end{array}$ & & $v$ & & & v & v & v & & $v$ & \\
\hline $\begin{array}{l}\text { Fadhilah \& Andriyansah } \\
\text { (2017) }\end{array}$ & $v$ & & $v$ & $v$ & $v$ & & & $v$ & & \\
\hline Fernando et al. (2016) & $\mathrm{V}$ & & & & & & & $\sqrt{ }$ & & \\
\hline Fitria \& Yuliana (2018) & & & & $\mathrm{v}$ & & & & $v$ & & \\
\hline $\begin{array}{l}\text { Hadiwijoyo, Purwanto, \& Hadi } \\
\text { (2013) }\end{array}$ & & & & & & & & & $\checkmark$ & \\
\hline Handayani et al. (2017) & $\mathrm{V}$ & & $\mathrm{V}$ & $\mathrm{v}$ & & $\mathrm{V}$ & & $\mathrm{v}$ & & \\
\hline Herman \& Anggraeni (2015) & $\mathrm{V}$ & & $\mathrm{V}$ & $\mathrm{v}$ & $\sqrt{ }$ & & & $\sqrt{ }$ & & \\
\hline Heryanto et al. (2014) & $\mathrm{V}$ & & & & & & & & $\checkmark$ & \\
\hline $\begin{array}{l}\text { Latupeirissa \& Adhariani } \\
\text { (2020) }\end{array}$ & 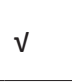 & & V & & & & & $v$ & & \\
\hline Lumbanbatu \& Aryanto (2015) & & & $\mathrm{V}$ & $\mathrm{v}$ & $\sqrt{ }$ & $\sqrt{ }$ & & $\sqrt{ }$ & & \\
\hline Muafi (2015) & $\mathrm{V}$ & & & & & $\sqrt{ }$ & & $v$ & & \\
\hline (Pemayun \& Suprapti, 2016) & $\mathrm{V}$ & & & $\mathrm{v}$ & $\sqrt{ }$ & & & & $\sqrt{ }$ & \\
\hline (Rajiani \& Kot, 2018) & & & & & & & & & $\mathrm{v}$ & \\
\hline (Sari \& Kusumastuti, 2018) & $\mathrm{V}$ & & & & $\sqrt{ }$ & $\sqrt{ }$ & & $\mathrm{v}$ & & \\
\hline (Setiawati et al., 2014) & & & $\mathrm{V}$ & & & $\sqrt{ }$ & & & $\checkmark$ & \\
\hline (Setyawati et al., 2014) & & & & & $\sqrt{ }$ & $\sqrt{ }$ & & & 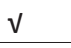 & \\
\hline $\begin{array}{l}\text { (Somjai, Fongtanakit, \& } \\
\text { Laosillapacharoen, 2020) }\end{array}$ & $\mathrm{V}$ & & & $v$ & v & & & $v$ & & \\
\hline (Sulistiyani, 2018) & & & & & & & $\sqrt{ }$ & & & $\sqrt{ }$ \\
\hline (Sutanto, 2018) & & & & $\mathrm{v}$ & $\mathrm{V}$ & & & $\mathrm{v}$ & & \\
\hline (Wen \& Harris, 2020) & & & $\mathrm{V}$ & $\mathrm{v}$ & & $\sqrt{ }$ & & $\mathrm{V}$ & & \\
\hline (Wibowo et al., 2019) & & & $\mathrm{V}$ & 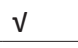 & $\sqrt{ }$ & $\sqrt{ }$ & & $v$ & & \\
\hline (Zandi, Ghani, et al., 2019) & & & $\mathrm{V}$ & $\mathrm{v}$ & $\mathrm{V}$ & & & $\mathrm{v}$ & & \\
\hline (Zandi, Khalid, et al., 2019) & & $\mathrm{v}$ & & $\mathrm{v}$ & & & & $v$ & & \\
\hline Total & 10 & 2 & 11 & 14 & 14 & 10 & 3 & 19 & 9 & 1 \\
\hline
\end{tabular}

Notes: $\mathrm{DRI}=$ Driver, $\mathrm{RND}=\mathrm{R} \& \mathrm{D}, \mathrm{PFI}=$ Performance financial, $\mathrm{PNF}=$ Performance Non-financial, PDEI=Product eco-innovation, $\mathrm{PCEI}=$ Process eco-innovation, $\mathrm{OGEI}=$ Organizational eco-innovation, $\mathrm{COM}=$ Company, ENV=Environmental, $\mathrm{PLC}=$ Policy

Purwanto, \& Hadi, 2013), specific industry such as seaweed industry and eco-innovation park as becoming analysis focus from (Setyawati, Maarif, $\&$ Arkeman 2014). The only study focused on the policy was conducted by Sulistiyani (2018) who analyzed various policies regarding green village innovation in Yogyakarta.

\section{g. Future research directions}

The analysis shows that studies on eco-innovation in Indonesia were lacking. Only less than five articles per year compared to hundreds of articles published globally per year. Therefore, opportunities for exploration are still widely open. Based on the analysis, some future research avenues across different themes can be identified. 
First, empirical research on drivers of eco-innovation is needed. Research can explore various factors that motivate companies in Indonesia to adopt eco-innovation. These factors can be in the form of basic characteristics of the company, such as age or size, which so far provides inconclusive results (Díaz-García et al., 2015); company's strategy such as the vision of top management, cost strategy, differentiation strategy; or company's capabilities, such as productions, marketing, financial, or technological. Different factors can also be explored that might motivate companies to develop eco-innovation, as has been done in one of the articles reviewed, highlighting the linkage between political connections and eco-innovation (Latupeirissa \& Adhariani, 2020); alternatively, cultural factors that might be unique in the case of Indonesia. Not to mention meso factors such as industry and market dynamics and macro factors such as regulation or regional factors.

Second, the opportunity is widely open for research by emphasizing the process of developing eco-innovation in companies through $R \& D$ because it was rarely investigated by researchers in Indonesia. Eco-innovation is strongly connected to the company's investment in R\&D (Lee \& Min, 2015). In the context of eco-innovation, this type of $R \& D$ is known as green $R \& D$. Research can identify the company's best practices in terms of eco-innovation in Indonesia and analyzing how they conduct green R\&D. Research can also be carried out to analyze the relationship between green R\&D investment and company's performance.

Third, although the relationship between eco-innovation and the company's performance has been considerably studied, the result is inconclusive. Hence, research on this relationship is still open. Future empirical research can examine the relationship of various eco-innovation drivers and/or the eco-innovation implementation with financial and non-financial performance using a quantitative approach involving a large sample. A meta-analysis approach can also be carried out on existing results to determine the overall effects of eco-innovation on a company's performance.
Fourth, the product and process eco-innovation are two types of eco-innovation that have received ample attention. The eco-innovation type that has not yet received much attention is organizational eco-innovation, which can be in the form of an implementation environmental management system (EMS) such as ISO 14001 or in the form of a formal company policy. Other organizational eco-innovation practices that can be investigated are green supply chain management or green sourcing to support the development of eco-innovation.

Fifth, the level of analysis that has not been much researched is the business environment (meso level), such as market dynamics or the influence of pressure groups on the development of eco-innovation. Furthermore, the research that is still very rare is at the macro level, such as analysis of policy instruments and innovation systems that can be conducive to the development of eco-innovation in Indonesia.

In addition to the five future research avenues, it is strongly encouraged to have research using different methodological approaches. As various publications are dominated by quantitative approaches, qualitative approaches and/or mixed methods were rare. Qualitative studies have the advantage of being able to generate rich data (Silverman, 2016), while the mixedmethod study can provide a more comprehensive understanding of the issues studied (Creswell \& Creswell, 2018). Qualitative studies and/or mixed methods, for example, can be aimed at revealing success factors in innovating at companies that have won green industry awards (Kemenperin, 2019). Likewise, publications in high-ranking international journals (SJR Q1) or in journals that have impact factors were rare; only one article in SJR Q1 and only two articles published in journals with impact factors. By disseminating in the higher ranking journals, it is expected research on eco-innovation in Indonesia could make a more significant contribution both theoretically to the body of knowledge of eco-innovation as well as to practice. 


\section{CONCLUSION}

Studies on eco-innovation in Indonesia have received increasing attention in recent years. However, the number of publications in academic journals was scarce when compared to the publications at the international level. Therefore, opportunities to explore and contribute both academically and practically are still widely open. Academically, this paper can be useful to advance our understanding of the current state of eco-innovation research in Indonesia and various possible future research directions. Practically, it may be useful for practitioners to gain insight on the advancement of their business through ecoinnovation. For policymakers, this paper can be used to find out the priority development areas for eco-innovation in Indonesia in the future.

This study has several limitations. First, only articles published in academic journals are reviewed. It is possible that unpublished research projects or relevant works were published in non-academic journals such as websites, blogs, or newspaper articles. It is interesting to explore how eco-innovation in Indonesia develops outside academic journals.

Second, this study is limited to ecoinnovation, and not to a broader scope such as eco-industry or to similar but different types of innovations such as frugal innovation or wider scope of such as sustainability innovation. It is interesting to discuss the development of research on various related topics, which involves relevant key terms that have not been used in this study, such as 'environmental innovation'.

Third, this study is limited to the Indonesian context. Besides having advantages because it can provide a current state of the development of this field in Indonesia, it also becomes a limitation because the results of this study are only relevant to the Indonesian context. It is interesting to benchmark with regional peers or elaborate deeper on the academic and practice contributions of eco-innovation research in Indonesia in the development of this field internationally.

\section{REFERENCES}

Alamsyah, D.P., Syarifuddin, D., \& Mohammed, H.A.A. (2018). Green customer behavior on eco-friendly products: Innovation approach. Jurnal Dinamika Manajemen, 9(2), 159-169. https://doi.org/10.15294/jdm.v9i2.15386

Alvin, (2018). Pengaruh green perceived value, green product innovation, green self identity, brand credibility terhadap green purchase intention melalui green brand equity pada produk skin-care Korea di Indonesia. Jurnal Manajemen Bisnis dan Kewirausahaan, 2(6), 1-7. Retrieved from http://www.albayan.ae

Aragón-Correa, J.A., Hurtado-Torres, N., Sharma, S., \& García-Morales, V.J. (2008). Environmental strategy and performance in small firms: A resource-based perspective. Journal of Environmental Management, 86(1), 88-103.

Aryanto, V.D.W., Wismantoro, Y., \& Widyatmoko, K. (2019). Implementing Eco-innovation by utilizing the internet to enhance firm's marketing performance. Disruptive Technology, 1290-1307. https://doi.org/10.4018/978-15225-9273-0.ch062

Astuti, M., Prawoto, P., Irawan, Y.S., \& Sugiono, S. (2018). The eco-innovation variables which influence the performance of creative industries center of natural stone crafts. Journal of Ecological Engineering, 19(1), 14-24. https:// doi.org/10.12911/22998993/79446

Astuti, M., Prawoto, P., Irawan, Y.S., \& Sugiono, S. (2019). The role of university in the implementation of eco-innovation in creative industry center of the natural stone crafts. International Journal of Integrated Engineering, 11(5), 58-65. https://doi.org/10.30880/ ijie.2019.11.05.008

Bos-brouwers, H.E.J. (2010). Corporate sustainability and innovation in SMEs: Evidence of themes and activities in practice. Business Strategy and the Environment, 19, 417-435.

Clarivate Analytics, (2018). Journal citation reports. Retrieved on March 26, 2020, from https://jcr. clarivate.com.

Cornell University, INSEAD \& WIPO. (2020). Global innovation index 2020: Who will finance innovation? world intellectual property organization (13th ed.). Retrieved from https://www.wipo.int/edocs/pubdocs/en/ wipo_pub_gii_2019-chapter1.pdf.

Creswell, J.W. \& Creswell, J.D. (2018). Research design: Qualitative, quantitative, and mixed methods approaches (5th ed.). California, US: SAGE Publication. https://doi.org/10.1017/ CBO9781107415324.004. 
De Marchi, V. (2012). Environmental innovation and R\&D cooperation: Empirical evidence from Spanish manufacturing firms. Research Policy, 41(3), 614-623. https://doi.org/10.1016/j. respol.2011.10.002

Denyer, D. and Tranfield, D. (2009). Producing a systematic review. In D. Buchanan and A. Bryman (Eds.), The SAGE handbook of organizational research methods. California, US: : SAGE Publications Ltd.

Díaz-García, C., González-Moreno, Á., \& SáezMartínez, F.J. (2015). Eco-innovation: Insights from a literature review. Innovation: Management, Policy and Practice, 17(1), 6-23. https:// doi.org/10.1080/14479338.2015.1011060

Fadhilah, M. \& Andriyansah. (2017). Strategic implementation of environmentally friendly innovation of small and medium-sized enterprises in Indonesia. European Research Studies Journal, 20(4), 134-148. https://doi.org/10.35808/ ersj/880

Fernández-Viñé, M.B., Gómez-Navarro, T., \& Capuz-Rizo, S.F. (2010). Eco-efficiency in the SMEs of Venezuela. Current status and future perspectives. Journal of Cleaner Production, 18(8), 736-746. https://doi.org/10.1016/j. jclepro.2009.12.005

Fernando, Y., Shaharudin, M.S., \& Wahid, N.A. (2016). Eco-innovation practices: A case study of green furniture manufacturers in Indonesia. International Journal of Services and Operations Management, 23(1), 43. https:// doi.org/10.1504/IJSOM.2016.073289

Fitria, S.E., \& Yuliana, E. (2018). The influence of eco-preneurship dimensions towards students' new business at Telkom University in Indonesia. International Journal of Business, 23(3), 270-283.

Geyh, S., Peter, C., Müller, R., Bickenbach, J.E., Kostanjsek, N., Üstün, B. T., Stucki, G., \& Cieza, A. (2011). The personal factors of the international classification of functioning, disability and health in the literature: A systematic review and content analysis. Disability and Rehabilitation, 33(13-14), 1089-1102. https:// doi.org/10.3109/09638288.2010.523104

Gumbira, G. and Harsanto, B. (2019). Decision support system for an eco-friendly integrated coastal zone management (ICZM) in Indonesia. International Journal on Advanced Science Engineering Information Technology, 9(4), 1177-1182.
Hadiwijoyo, R., Purwanto, P., \& Hadi, S.P. (2013). Innovative green technology for sustainable industrial estate development. International Journal of Renewable Energy Development, 2(1), 53-58. https://doi.org/10.14710/ ijred.2.1.53-58

Handayani, R., Wahyudi, S., \& Suharnomo, S. (2017). The effects of corporate social responsibility on manufacturing industry performance: The mediating role of social collaboration and green innovation. Business: Theory and Practice, 18, 152-159. https://doi.org/10.3846/btp.2017.016

Harsanto, B., Kumar, N., Zhan, Y., \& Michaelides, R. (2020). Exploring sustainability-oriented innovation capabilities in the Indonesian manufacturing firms. Academy of Management Proceedings, (1), 14242. https://doi. org/10.5465/AMBPP.2020.14242abstract

Harsanto, B., Michaelides, R., \& Drummond, H. (2018). Sustainability-oriented innovation (SOI) in emerging economies: A preliminary investigation from Indonesia. In 2018 IEEE International Conference on Industrial Engineering and Engineering Management (IEEM) (pp. 1553-1557). Bangkok, Thailand: IEEE. https://doi.org/10.1109/IEEM.2018.8607473

Harsanto, B. \& Permana, C.T. (2019). Understanding sustainability-oriented innovation (SOI) using network perspective in Asia Pacific and ASEAN : A systematic review. Journal of Asean Studies, 7(1), 1-17.

Harsanto, B. \& Permana, C.T. (2020). Sustainabilityoriented innovation ( SOI ) in the cultural village : An actor-network perspective in the case of Laweyan Batik Village. Journal of Cultural Heritage Management and Sustainable Development. https://doi.org/10.1108/ JCHMSD-08-2019-0102

Hazarika, N. \& Zhang, X. (2019). Evolving theories of eco-innovation: A systematic review. Sustainable Production and Consumption, 19, 64-78. https://doi.org/10.1016/j.spc.2019.03.002

Herman, L.E. \& Anggraeni, A.I. (2015). Nurturing green product into globalization: Challenges and opportunities over Indonesian smes. International Journal of Applied Business and Economic Research, 13(7), 6199-6215.

Heryanto, M.A., Sukayat, Y., \& Supyandi, D. (2014). The conception-adoption model of organic rice innovation: Farmer's Social economy (case study in Tasikmalaya, West Java), 12(2), 139-150. 
Hitchens, D., Thankappan, S., Trainor, M., Clausen, J., \& Marchi, B.D.E. (2005). Environmental performance, competitiveness and management of small businesses in Europe, 96(5), 541-557.

Horbach, J. (2008). Determinants of environmental innovation: New evidence from German panel data sources. Research Policy, 37(1), 163-173. https://doi.org/10.1016/j.respol.2007.08.006

Howgrave-Graham, A. \& van Berkel, R. (2007). Assessment of cleaner production uptake: Method development and trial with small businesses in Western Australia. Journal of Cleaner Production, 15(8-9), 787-797. https:// doi.org/10.1016/j.jclepro.2006.07.004.

Hsieh, H.F. \& Shannon, S.E. (2005). Three approaches to qualitative content analysis. Qualitative Health Research, 15(9), 1277-1288. https:// doi.org/10.1177/1049732305276687.

Jo, J.H., Roh, T.W., Kim, S., Youn, Y.C., Park, M.S., Han, K.J., \& Jang, E.K. (2015). Eco-Innovation for sustainability: Evidence from 49 countries in Asia and Europe. Sustainability (Switzerland), 7(12), 16820-16835. https://doi.org/10.3390/ su71215849.

Kemenperin. (2016). Indonesia Masih perlu inovasi industri hijau. Retrieved on October 5, 2020, from https:/www.kemenperin.go.id/ artikel/15963/Indonesia-Masih-Perlu-InovasiIndustri-Hijau.

Kemenperin. (2019). Kemenperin: Penghargaan Industri Hijau 2019. Retrieved on June 27, 2020, from https://kemenperin.go.id/artikel/20754/ Penghargaan-Industri-Hijau-2019.

Kemp, R. \& Pearson, P. (2007). Final report MEI project about measuring eco-innovation. UM Merit, Maastricht, 10, 2.

Kesidou, E. \& Demirel, P. (2012). On the drivers of eco-innovations: Empirical evidence from the UK. Research Policy, 41(5), 862-870. Retrieved from http://dx.doi.org/10.1016/j. respol.2012.01.005

Kiefer, C.P., Carrillo-Hermosilla, J., Del Río, P., \& Callealta Barroso, F.J. (2017). Diversity of ecoinnovations: A quantitative approach. Journal of Cleaner Production, 166, 1494-1506. https://doi.org/10.1016/j.jclepro.2017.07.241

Klewitz, J. \& Hansen, E.G. (2014). Sustainabilityoriented innovation of SMEs: A systematic review. Journal of Cleaner Production, 65, $57-75$.

Krippendorff, K. (1980). Validity in Content Analysis. Computerstrategien Für Die Kommunikationsanalyse, 69-112. Retrieved from http:// repository.upenn.edu/asc_papers/291.
Latupeirissa, G. \& Adhariani, D. (2020). External and internal economic impacts of eco-innovation and the role of political connections: A sustainability narrative from an emerging market. Journal of Cleaner Production, 258, 120579. https://doi.org/10.1016/j.jclepro.2020.120579

Lee, K.H. \& Min, B. (2015). Green R\&D for eco-innovation and its impact on carbon emissions and firm performance. Journal of Cleaner Production, 108, 534-542. https://doi.org/10.1016/j. jclepro.2015.05.114.

Lumbanbatu, K. \& Aryanto, V.D.W. (2015). Green Practices implementation as prerequisite to sustain firm competitive advantages: The empirical study from indonesia large scale enterprises (LSEs). International Journal of Social Ecology and Sustainable Development, 6(4), 34-53.

Machiba, T. (2010). Eco-innovation for enabling resource efficiency and green growth: Development of an analytical framework and preliminary analysis of industry and policy practices. International Economics and Economic Policy, 7(2), 357-370. https://doi.org/10.1007/s10368010-0171-y.

Ministry of Environment and Forestry Indonesia, (2017). Statistik lingkungan hidup dan kehutanan. Retrieved from https://doi.org/10.1017/ CBO9781107415324.004.

Moher, D., Liberati, A., Tetzlaff, J., Altman, D.G., Altman, D., \& The PRISMA Group. (2009). Preferred reporting items for systematic reviews and meta-analyses: The PRISMA statement. PLoS Medicine, 6(7). https://doi.org/10.1371/ journal.pmed.1000097.

Muafi. (2015). Green IT empowerment, social capital, creativity and innovation: A case study of creative city, Bantul, Yogyakarta, Indonesia. Journal of Industrial Engineering and Management, 8(3), 719-737. https://doi.org/10.3926/ jiem.1341.

OECD. (2019). Tinjauan OECD terhadap kebijakan pertumbuhan hijau Indonesia 2019. https://doi. org/10.1787/5668086d-id.

Pemayun, A.A. \& Suprapti, N.W.S. (2016). Pengaruh etika lingkungan perusahaan terhadap keunggulan kompetitif: Peran mediasi inovasi produk hijau. E-Jurnal Manajemen Unud, 5(9), 5895-5922.

Rajiani, I. \& Kot, S. (2018). The prospective consumers of the Indonesian green aviation initiative for sustainable development in air transportation. Sustainability (Switzerland), 10(6). https://doi. org/10.3390/su10061772. 
Sari, D.P. \& Kusumastuti, R. (2018). The analysis of firm financial performance influence towards eco-innovation on indonesian consumer goods companies. Hasanuddin Economics and Business Review, 2(1), 61. https://doi.org/10.26487/ hebr.v2i1.1475

Schiederig, T., Tietze, F., \& Herstatt, C. (2012). Green innovation in technology and innovation management: An exploratory literature review. R\&D Management, 42(2), 180-192.

Setiawati, S., Alikodra, H., Pramudya, B., \& Dharmawan, A.H. (2014). Model of water, energy and waste management for development of eco-innovation park: A Case study of Center for Research of Science. World Technopolis Association, 3(2), 89-96.

Setyawati, E., Maarif, M.S., \& Arkeman, Y. (2014). Inovasi hijau dalam industri pengolahan rumput laut semi refineed carrageenan (Src). Jurnal Teknik Industri, 4(1). https://doi.org/10.25105/ jti.v4i1.1559

Silverman, D. (2016). Qualitative Research. California, US: SAGE.

Somjai, S., Fongtanakit, R., \& Laosillapacharoen, K. (2020). Impact of environmental commitment, environmental management accounting and green innovation on firm performance: An empirical investigation. International Journal of Energy Economics and Policy, 10(3), 204-210. https://doi.org/10.32479/ijeep.9174

Stemler, S. (2001). An overview of content analysis. Practical Assessment, Research and Evaluation, 7(17), 2000-2001. https://doi. org/10.1362/146934703771910080

Sulistiyani, A.T. (2018). Environmental policy evaluation in green village innovation in Yogyakarta Special Region. Journal of Public Administration and Local Governance, 2(1), 1-8.

Sutanto, S.M. (2018). “Clever little bag” green packaging inovation from Puma. Journal of Visual Communication Design, 3(1).

Triguero, A., Moreno-Mondéjar, L., \& Davia, M.A. (2013). Drivers of different types of ecoinnovation in European SMEs. Ecological Economics, 92, 25-33. https://doi.org/10.1016/j. ecolecon.2013.04.009.
Varadarajan, R. (2017). Innovating for sustainability: A framework for sustainable innovations and a model of sustainable innovations orientation. Journal of the Academy of Marketing Science, 45(1), 14-36.

Wen, V. \& Harris, I. (2020). Pengaruh inovasi lingkungan dan inovasi layanan pada kinerja bisnis yang berkelanjutan (studi pada perusahaan teknologi di batam). DeReMa (development of research management): Jurnal Manajemen, 15(1), 82-103.

Wibowo, S.F., Ahmad, G.N., \& Fauzi, A. (2019). Does green innovation matter? A study on Indonesia's SMEs. Jurnal Manajemen, 23(1), 100. https://doi.org/10.24912/jm.v23i1.447.

Xavier, A.F., Naveiro, R.M., Aoussat, A., \& Reyes, T. (2017). Systematic literature review of eco-innovation models: Opportunities and recommendations for future research. Journal of Cleaner Production, 149, 1278-1302. https:// doi.org/10.1016/j.jclepro.2017.02.145

Zandi, G.R., Ghani, E.K., Lestari, R.M.E., \& Maimunah, S. (2019). The impact of management accounting systems, eco-innovations and energy efficacy on firm's environmental and economic performance. International Journal of Energy Economics and Policy, 9(6), 394-400. https://doi.org/10.32479/ijeep.8364

Zandi, G.R., Khalid, N., \& Islam, D.M.Z. (2019). Nexus of knowledge transfer, green innovation and environmental performance: impact of environmental management accounting. International Journal of Energy Economics and Policy, 9(5), 387-393. https://doi. org/10.32479/ijeep.8285.

Zhang, J.A., \& Walton, S. (2017). Eco-innovation and business performance: the moderating effects of environmental orientation and resource commitment in green-oriented SMEs. $R$ and D Management, 47(5), E26-E39. https://doi. org/10.1111/radm.12241. 